\title{
ЭПИДЕМИЯ COVID-19 И МАШИНОСТРОЕНИЕ: ОПЫТ КНР
}

\section{Александр АКИМов}

Рассмотрены меры стимулирования машиностроительных отраслей китайской экономики, направленные на противодействие спаду, обусловленному пандемией коронавируса COVID-19 и торможением вследствие этого мировой экономики.

КНР, как страна, первая столкнувшаяся с эпидемией коронавируса COVID-19, показывает реакцию общества и экономики на это событие и пути решения проблем, связанных с чрезвычайной ситуацией. Опубликованные данные по отдельным подотраслям позволяют представить общую картину.

По сообщениям кабинета министров КНР, министерства промышленности и информационных услуг (The Ministry of Industry and Information Technology), которое определяет планирование и политику в промышленности Китая и осуществляет контроль за повседневной работой промышленных предприятий и отраслевых объединений, машиностроение Китая пережило в первом квартале существенный спад из-за прекращения работы в связи с карантином, нарушения поставок и уменьшения спроса.

Общая прибыль в производстве электроники в первые два месяца 2020 года упала на $87 \%$ в годовом исчислении, в то время как операционная выручка упала на $14,7 \%$ по сравнению с предыдущим годом. В целом прибыль подсектора по производству оборудования связи упала в 3,5 раза по сравнению с предыдущим годом, в то время как прибыль подсектора по производству компьютеров снизилась почти в 1,5 раза. За первые два месяца производство мобильных телефонов упало на $33,8 \%$ в годовом исчислении, а производство смартфонов на $32,5 \%$. Объем производства ноутбуков и план- шетов снизился на 31,1 и $24,5 \%$ соответственно.

К концу марта производственный сектор Китая постепенно восстановил производство, причем 98,6\% крупных промышленных фирм по всей стране возобновили работу. Около 89,9\% сотрудников промышленных компаний с годовым доходом более 20 млн юаней (2,84 млн долл.) вернулись на рабочие места [1].

Особо пострадало автостроение. Производство автомобилей в Китае испытывало трудности еще в 2019 году, но в 2020-м центром эпидемии стал город Ухань, который является крупным центром автопрома. В начале 2020го продажи автомобилей в КНР упали до уровня 2005 года в результате снижения спроса и сокращения выпуска в период эпидемии. Тем не менее возврат к уровням производства, нормальным до эпидемии, был быстрым. В марте выпуск автомобилей увеличился в четыре раза по сравнению с февралем, а продажи примерно в 3,5 раза [2].

Для решения возникших проблем в первом квартале 2020 года бизнес активно брал кредиты. Заимствования составили почти 7 трлн юаней (около 988 млрд долл.) [3], что на 20\% больше, чем за аналогичный период прошлого года.

Министерством торговли Китая предприняты меры по стимулированию потребления внутри страны той продукции, которая при отсутствии пандемии и глобального экономического спада предна- 
значалась на экспорт [4]. Это было необходимо в условиях спада спроса на экспортных рынках.

Бизнес также включился в борьбу с эпидемией. Старейшая в стране автомобилестроительная фирма FAW Group основала специальный фонд для борьбы с эпидемией в провинции Хубэй, где расположен город Ухань и где ситуация с распространением COVID-19 была наиболее серьезной. Ухань является важным центром производства автомобилей и комплектующих в Китае.

В то время как карантинные ограничения ослабевают, работа на производстве возобновляется, но вместе с соблюдением требований безопасности, вытекающих из характера эпидемии. Ряд ограничений сохраняется. В частности, отложена крупнейшая Кантонская ярмарка, которая проходит каждую весну и важна как мероприятие по продвижению китайского экспорта в мире.

В первом полугодии сокращалась прибыль основных промышленных фирм КНР, но по данным National Bureau of Statistics, по итогам первого полугодия она оказалась на 11,5\% выше прошлогоднего уровня [5].
В целом, машиностроение оказалось, по крайнем мере в КНР, вполне устойчивым в условиях чрезвычайной ситуации, связанной с эпидемией, а временный спад был быстро компенсирован.

\section{ЛИТЕРАТУРА}

1. China's electronic information manufacturing reports lower profits. www.gov.cn

2. China's progress on business resumption // www.gov.cn

3. China's Q1 new loans reach nearly $7 \mathrm{t}$ yuan to support virus-hit economy // www.gov.cn

4. China supports domestic sales of export goods, foreign trade firms Registration Number: 05070218 www.gov.cn

5. China's industrial profits up $11.5 \%$ in June $/ /$ www.gov.cn

\section{АКимОВ Александр Владимирович -}

доктор экономических наук, заведующий отделом экономических исследований Института востоковедения РАН
Одновременно

С СИБИРСКИМ ЭНЕРГЕТИЧЕСКИМ ФОРУМОМ и выставкой «НЕФТЬ. ГАЗ. ХИМИЯ»

25-27 ноявря
2020 KPACHOЯPCK

\section{XV СПЕЦИАЛИЗИРОВАННАЯ ВЫСТАВКА}

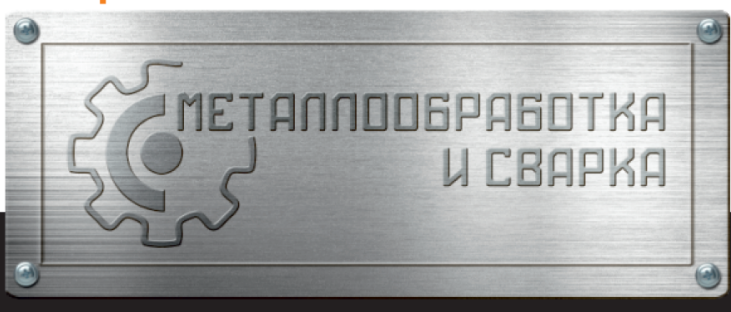

Оборудование мировых брендов в действии!

- Машиностроение. Станкостроение - Дефектоскопия

- Металлургия. Металлообработка • Литье. Сварка

- Инструменты. Метизы

- Охрана труда на предприятии

Межрегиональный конкурс «Сварщик года - 2020»

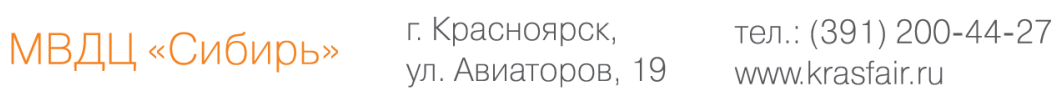

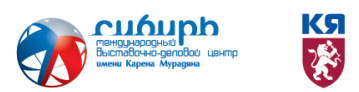

